Collection: IUFRO 7.01.00 - Ithéus (Brazil, 2013) \& Beijing (China, 2014)

"Forest Response to Climate Change and Air Pollution"

Guest Editors: Paoletti E, Kozovitz A, Feng Z, Bytnerowicz A

\section{Role of forest cover, land use change and climate change on water resources in Marmara basin of Turkey}

\author{
Pinar Pamukcu, Yusuf Serengil, Ibrahim Yurtseven
}

\begin{abstract}
We evaluated the influence of climate change and land use changes on water resources in the Marmara Region (Turkey) using the watershed runoff coefficients (RC) and trend analysis techniques on long-term (30 years) hydrometerological data. Land use changes in the selected sub-watersheds were obtained from CORINE land use maps for 1990, 2000, and 2006, and interpolated for annual changes. Forty-two land use types of Corine maps were grouped in four basic classes (forests, rangelands, farmlands, settlements). Principal component analysis was used to identify the most relevant land use types influencing RC since 1990. Results showed that changes in the proportion of forestlands, farmlands, and rangelands significantly affected RC. Settlements also affected RC, but to a lesser extent. RCs values for the different land use types were optimized on a subset of 28 out of the 48 sub-watersheds analyzed by minimizing the sum of least-square errors, while the remaining subset of 20 sub-watersheds was used to validate the models obtained. The $\mathrm{R}^{2}$ values for optimization and validation were 0.80 and 0.70 , respectively. RCs of all watersheds were estimated for the period 1990-2012. Long-term trends in mean annual precipitation and temperature were examined by Mann-Kendall test based on time series from eight weather stations with records since 1930s. Contrasting significant trends of variation through time were found only for two stations as for precipitation, and for one station as for temperature. Overall, our results suggest that significant land use changes occurred in the region since 1990 , but only slight variations in climate parameters. However, we conclude that neither land use changes nor the variation in climate parameters caused statistically significant effects on RCs and water resources.
\end{abstract}

Keywords: Climate Change, Land Use Change, Water Resources, Runoff Coefficient

\section{Introduction}

Urbanization is a major driver of land use change and is extensively studied in land use literature, especially in disciplines like landscape ecology and watershed science. Some research focused on certain land use types (Atmis et al. 2007, Shiliang et al. 2014), while others tried to identify their impacts on biodiversity, forests and water ( $\mathrm{Du}$ et al. 2012, Zapata \& Robledano 2014). Impacts

on society and natural resources have been frequently emphasized in these studies. Urbanization and associated sprawl cause changes in society and environment and therefore interact with broader issues like climate and water resources.

Water is becoming a critical natural resource for Turkey with its fast urbanization trend (Serengil et al. 2012). The increasing population in big cities causes constantly in-

Faculty of Forestry, Istanbul University, Istanbul (Turkey)

@ Yusuf Serengil (serengil@istanbul.edu.tr)

Received: Jan 15, 2014 - Accepted: Aug 09, 2014

Citation: Pamukcu P, Serengil Y, Yurtseven I, 2014. Role of forest cover, land use change and climate change on water resources in Marmara basin of Turkey. iForest 8: 480-486 [online 2014-10-31] URL: http://www.sisef.it/iforest/contents/?id=ifor1242-007

Communicated by: Elena Paoletti creasing demand of water. New water resources have been identified and pipeline projects have been developed and implemented in the last 20 years. Melen and Istranca projects are examples of expensive long-range, trans-basin projects (ISKI 2013) supposed to meet the water demand of Istanbul for the next 10-15 years. However, threats that may break down this optimistic prevision include: deterioration of reservoirs, increasing per capita water use, variability in precipitation, and increase in evapotranspiration rates due to gradual long-term changes in temperature and precipitation conditions.

Forest cover in Turkey has been increasing in the last five decades due to afforestation efforts and abandonment of farmlands in the countryside (NIR Turkey 2013). This increase has hydrological consequences as forests can significantly influence flows and conditions in a watershed (Serengil et al. 2011). Given that groundwater potential of Istanbul is low, the share of surface water resources is at $98 \%$ (ISKI 2013). This causes water supply to be strongly dependent on annual precipitation and the prevailing land use. In years of low precipitation, there is always a possibility of gap between supply and demand (deficit) during late summer months.

Though not supported by solid scientific evidence, two major problems have often been identified by local authorities towards the sustainable management of water resources of the region, i.e., climate change and land use conversion in watersheds.

Climate change is today's most remarkable threat towards the sustainability of natural resources (Delgado et al. 2013). Expected and (partly) realized changes in temperature and precipitation (Morrison et al. 2002, Tripathi et al. 2006, Ribalaygua et al. 2013, Quirmbach et al. 2012, Kyselý et al. 2012) as well as the response of ecosystems to projected changes in climatic parameters and atmospheric composition, have been studied thoroughly (Karnosky 2003, Senatore et al. 2012, Yang et al. 2012, Dibike et al. 2012). According to these studies, changes in precipitation or temperature or both would have consequences on evapotranspiration conditions and the water budget. As reported by Nan et al. (2011), temperature, precipitation and evaporation conditions determine the response of watershed hydrological systems. Changes may increase or decrease runoff trends and also annual water supply. Possible impacts of such changes on water resources in Turkey have not been evaluated yet (NC Turkey 2013).

While governmental water agencies are seeking new water resources, existing resources are occupied by settlements or farmlands (i.e., Kucukcekmece, Elmali). Governments and municipalities in Turkey face the 


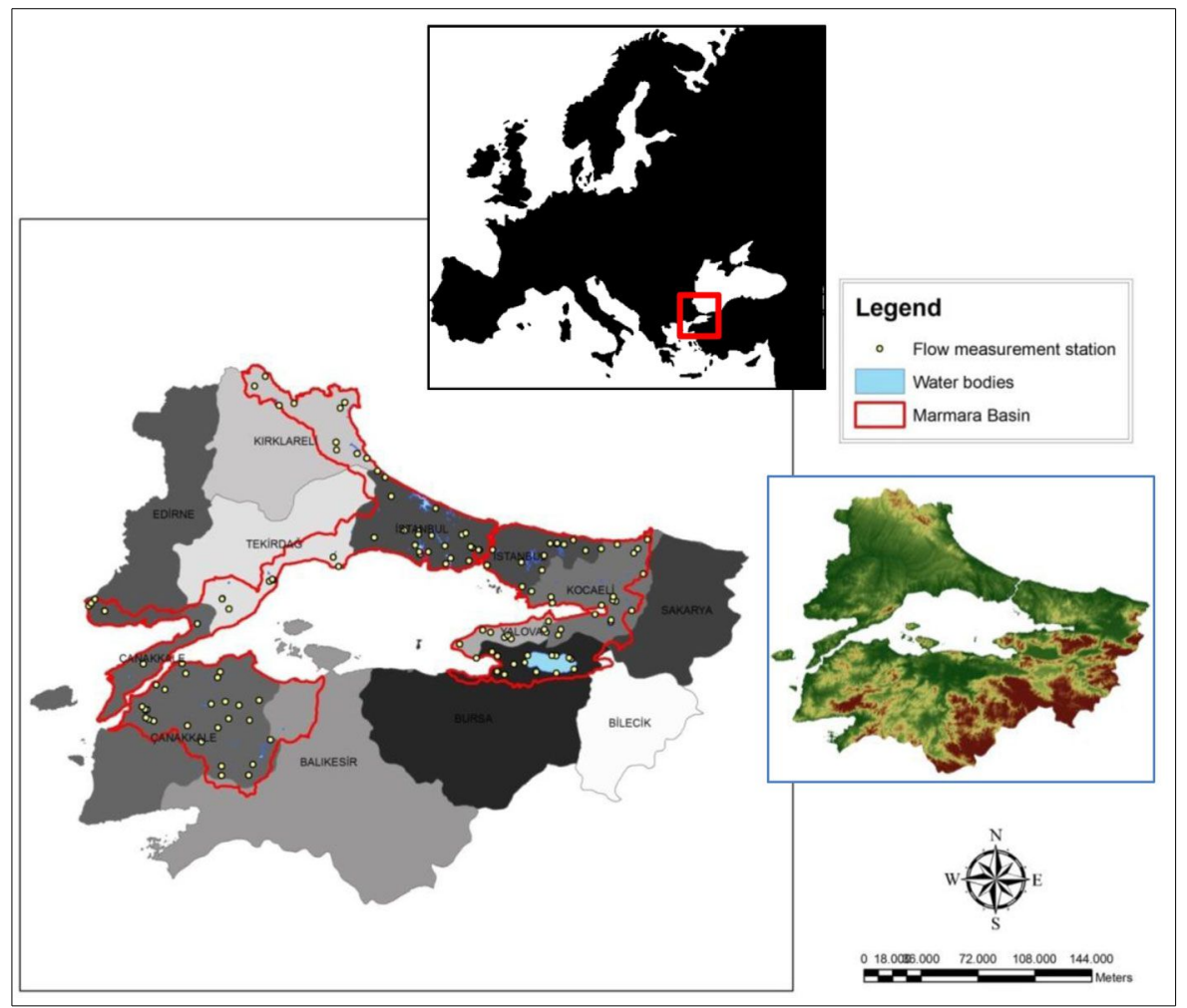

Fig. 1 - The Marmara basin (Turkey) and the location of the streamflow monitoring stations (white circles) operated by the State Hydraulic Works (DSI). Digital elevation model of the region is reported in the right box.

difficult task of minimizing urban development in reservoir watersheds. On the other hand, airport, highway, and sport arena projects causing massive urban developments in watersheds have been encouraged. Moreover, many residential projects have been implemented to accommodate thousands of people migrating to Istanbul every year. Consequently, settlements and associated conversions for additional resources (i.e., agricultural products, livestock) have caused broad scale land use changes in Marmara region of Turkey during the last 30 years.

Land use is one of the primary determinants of water production. The influence of land use and land use change on water production has been investigated as for water quality (Schoonover et al. 2005, Tu 2009, León-Muñoz et al. 2013), quantity (Wang et al. 2013, Weatherhead \& Howden 2009), and regime (Sigaroodi \& Ebrahimi 2010, Romanowicz \& Osuch 2011). Based on these studies, significant determinants of water production are:

- forests ecosystems decrease water yield, increase quality, attenuate small scale floods, and regulate water regime in most cases;

- the influence of farmlands and rangelands on water production is very variable and depends on local management practices;
- settlements increase runoff volume by reducing interception losses and infiltration rates but may severely decrease water quality.

One of the most practical tools for analyzing land use influence on water production is the runoff coefficient (RC - Sriwongsitanon \& Taesombat 2011) that is calculated on an annual basis. RC is highly correlated with watershed imperviousness (Schueler 2004), the portion of watershed area covered by roads, houses, and other built environments. However, RC may also be affected by climatic, topographic and edaphic parameters. Therefore, RC on an annual basis should be used as an indicator, not as a determinant, for water yield. It is however used in simple flood estimation equations like the Rational method (Hromadtka \& Yen 1989) on event basis. The land use type determines infiltration capacity, evapotranspiration (ET) rate, and runoff type that affect RC. It may also reflect slope and topographic conditions. Furthermore, the RC of a watershed varies over time and space as topography and ET conditions change. There are several empirical models to estimate potential ET (i.e., Priestley-Taylor, Turc, Thorntwaite), but RC of a watershed can only be calculated by measured precipitation-runoff data.

In this paper, we hypothesize that changes in land use and climate occurred in the last
4-5 decades in the Marmara region affected water yield of watersheds. We used historical, hydrological, climatological, and land use change data. The results may help shaping future policies on water resources and land use management of the region and country.

\section{Material and methods}

\section{Study area}

Marmara basin $\left(24100 \mathrm{~km}^{2}\right)$ is located in the most industrialized region of Turkey with the highest population density (Özhan 2004). Average annual precipitation in the region ranges between 440 and $800 \mathrm{~mm}$. Istanbul is the largest city with a population of more than 14 million people, who demand a daily average of 2.6 million $\mathrm{m}^{3}$ of water (ISKI 2013). The demand is increasing every year, adding more pressure to the existing water resources and requiring efforts to explore new ones. The General Directorate of Water Works (DSI), a government agency responsible for the development of water resources, has established a relatively extensive monitoring network of water flow in the region (Fig. 1).

The climate is mild oceanic temperate, with a moderate soil water deficit in summer which increases from north to south. There is a strong seasonality in precipitation, with a 2-3 month long dry period in the summer and a rainfall peak in winter months (generally in January - Serengil et al. 2007). The region is surrounded by mountains up to $2500 \mathrm{~m}$ a.s.l. in the south and south-east, and up to $1000 \mathrm{~m}$ a.s.l. in the north-west (Istranca region). However, the Marmara basin does not include highlands and is generally flatter as compared with the rest of the country. Such region was chosen because of the higher number of flow measurement stations compared to other basins of Turkey, and also for its richness in water bodies and reservoirs.

\section{Watershed delineation and hydrological data}

Some 48 sub-watersheds with flow measurement stations of the State Hydraulic Works (DSI) operating since at least 10 years were selected (Tab. 1). The size of sub-watersheds ranged between 17 to $969 \mathrm{~km}^{2}$, though $80 \%$ varied between 20 to $200 \mathrm{~km}^{2}$.

Sub-watersheds were delineated using the $\mathrm{ARCHYDRO}^{\circledR}$ module and visually corrected in ArcGIS $^{\circledR}$ (ESRI, Redlands, CA, USA). We used daily stream flow data obtained from the monitoring stations to calculate annual water yield. However, the length of time series was not the same for all stations: most were starting from 1990s, while a few stations had data since 1960 s or 1970 s. Precipitation data were complete and did not include missing values. 
Tab. 1 - Sub-watersheds and hydrologic data used in this study. (RC): runoff coefficient; (a): IDW-interpolated.

\begin{tabular}{|c|c|c|c|c|c|c|c|c|}
\hline Sub-watershed & $\begin{array}{l}\text { Area } \\
\left(\mathrm{km}^{2}\right)\end{array}$ & $\begin{array}{c}\text { Mean } \\
\text { Discharge } \\
\left(\mathrm{m}^{3} / \mathbf{s}\right)\end{array}$ & $\begin{array}{l}\text { Precipitation } \\
\text { (mm/year) }\end{array}$ & $\begin{array}{c}\text { Water Yield } \\
\text { (mm/year) }\end{array}$ & $\mathbf{R C}$ & $\begin{array}{l}\text { Closest } \\
\text { Meteo Station }\end{array}$ & $\begin{array}{c}\text { Mean } \\
\text { Elevation } \\
\text { (m) }\end{array}$ & $\begin{array}{c}\text { Mean } \\
\text { Slope } \\
(\%)\end{array}$ \\
\hline Altinkulaç & 34.75 & 0.292 & 629.49 & 265.00 & 42.10 & Edremit & 274.18 & 24.29 \\
\hline Avcidere & 36.25 & 0.493 & 753.59 & 428.89 & 56.91 & Kocaeli & 553.40 & 41.15 \\
\hline Bayramdere & 69.99 & 0.46 & 621.15 & 207.27 & 33.37 & Çanakkale & 239.66 & 26.92 \\
\hline Çakildere & 55.04 & 0.346 & 727.47 & 198.25 & 27.25 & Kumköy & 154.44 & 10.53 \\
\hline Çinardere & 58.05 & 0.793 & 627.65 & 430.80 & 68.64 & Çanakkale & 217.86 & 21.41 \\
\hline Göçbeyli Deresi & 133.37 & 1.56 & 780.95 & 368.87 & 47.23 & Kocaeli & 222.69 & 15.92 \\
\hline Göksu Deresi & 394.03 & 6.01 & 792.45 & 481.01 & 60.70 & Kocaeli & 287.71 & 20.27 \\
\hline Isiklar Deresi & 141.23 & 1.41 & 599.08 & 314.85 & 52.55 & Tekirdag & 336.89 & 21.24 \\
\hline Isiklar Deresi & 60.57 & 0.449 & 583.33 & 233.77 & 40.08 & Tekirdag & 228.80 & 31.81 \\
\hline Istiranca & 291.48 & 2.34 & 674.21 & 253.17 & 37.55 & Kumköy & 207.56 & 14.08 \\
\hline Kabakoz Deresi & 80.21 & 1.35 & 824.25 & 530.78 & 64.39 & Kocaeli & 139.21 & 21.40 \\
\hline Kagithane & 175.91 & 2.04 & 941.98 & 365.72 & 38.82 & Kumköy & 94.29 & 15.96 \\
\hline Karadere & 22.38 & 0.21 & 766.50 & 295.91 & 38.61 & Yalova & 293.16 & 27.93 \\
\hline Karanlik Dere & 78.71 & 0.743 & 641.30 & 297.69 & 46.42 & Edremit & 546.94 & 30.76 \\
\hline Karasu-Incegiz & 183.8 & 0.959 & 704.46 & 164.54 & 23.36 & Kumköy & 147.95 & 10.78 \\
\hline Kaynarca & 82.01 & 0.466 & 626.88 & 179.19 & 28.58 & Edremit & 196.36 & 20.42 \\
\hline Kilinci Dere & 62.43 & 0.458 & 869.93 & 231.35 & 26.59 & Kumköy & 92.25 & 13.58 \\
\hline Kirazdere & 254.02 & 5.29 & 731.73 & 656.74 & 49.75 & Kocaeli & 841.72 & 39.32 \\
\hline K.Kumla Dere & 20.69 & 0.3 & 811.53 & 457.26 & 56.35 & Yalova & 452.12 & 34.66 \\
\hline Kocabag Deresi & 167.02 & 1.31 & 639.11 & 247.35 & 38.70 & Edremit & 493.32 & 28.74 \\
\hline Kocabag Deresi & 968.92 & 7.71 & 632.24 & 250.94 & 39.69 & Edremit & 306.55 & 22.71 \\
\hline Kocaçay & 48.36 & 0.958 & 647.44 & 624.72 & 56.49 & Edremit & 658.91 & 30.13 \\
\hline Kocaçay & 41.99 & 0.186 & 621.76 & 139.69 & 22.47 & Çanakkale & 392.67 & 28.12 \\
\hline Kocadere & 197.9 & 2.54 & 576.98 & 404.76 & 70.15 & Kirklareli & 521.12 & 26.43 \\
\hline Kocadere & 65.09 & 0.551 & 893.05 & 266.96 & 29.89 & Bursa & 568.89 & 32.08 \\
\hline Kocadere & 75.96 & 0.762 & 831.30 & 316.36 & 38.06 & Yalova & 634.98 & 38.99 \\
\hline Kovandere & 112.07 & 0.631 & 602.66 & 177.56 & 29.46 & Tekirdag & 183.37 & 10.46 \\
\hline Kovanlik & 73.5 & 2.423 & 652.13 & 1039.62 & 59.42 & Edremit & 730.82 & 45.60 \\
\hline Malava Deresi & 112.87 & 2.89 & 828.52 & 807.47 & 57.46 & Kumköy & 115.74 & 16.61 \\
\hline Ozan Deresi & 78.07 & 2.76 & 815.46 & 1114.89 & 36.72 & Kocaeli & 227.36 & 21.57 \\
\hline Pabuçdere & 85.26 & 1.01 & 616.87 & 373.58 & 60.56 & Kirklareli & 431.41 & 27.94 \\
\hline Sariçay & 212.07 & 0.998 & 615.35 & 148.41 & 24.12 & Çanakkale & 408.20 & 28.64 \\
\hline Sarisu-Izzettin & 79.82 & 1 & 755.76 & 395.09 & 52.28 & Kumköy & 87.79 & 12.52 \\
\hline Sellimandira & 54.28 & 1.49 & 782.23 & 865.67 & 70.67 & Yalova & 577.63 & 36.99 \\
\hline Suludere & 34.28 & 0.627 & 769.20 & 576.81 & 74.99 & Kocaeli & 550.75 & 41.17 \\
\hline Velikadere & 307.11 & 5.14 & 588.41 & 527.81 & 59.70 & Kirklareli & 532.59 & 24.65 \\
\hline Yagcidere & 17.27 & 0.2 & 770.75 & 365.21 & 47.38 & Yalova & 356.48 & 29.01 \\
\hline Yalakdere & 269.91 & 2.35 & 766.62 & 274.57 & 35.82 & Yalova & 358.15 & 30.86 \\
\hline Yenidüz Deresi & 105.63 & 2.01 & 789.22 & 600.09 & 76.04 & Kocaeli & 149.59 & 14.30 \\
\hline Yamandere & 31.04 & 0.346 & 808.10 & 351.53 & 43.50 & Bursa & 523.76 & 19.92 \\
\hline Yegildere & 58.43 & 1.32 & 830.18 & 712.43 & 45.82 & Kocaeli & 128.27 & 19.53 \\
\hline Yilgindere & 17.69 & 0.22 & 788.18 & 392.19 & 49.76 & Kocaeli & 145.74 & 21.37 \\
\hline Yulafli Dere & 207.05 & 2.27 & 778.49 & 345.75 & 44.41 & Kocaeli & 136.64 & 15.24 \\
\hline Gönen Çayi & 643.64 & 7.36 & 643.56 & 360.61 & 56.03 & Edremit & 505.44 & 28.96 \\
\hline
\end{tabular}

Eight weather stations having long-term climatic records starting from 1930s (mean annual temperature and precipitation) were identified in the study area, to be used in trend detection tests.

Land use change data was obtained from three consecutive CORINE maps prepared with the same methodology. We used CORINE 1990, 2000, and 2006 maps, which is a reliable data source of historical land uses in Turkey. CORINE maps are also the mapping system used for the National Greenhouse Gas Inventory Report (NIR) of Turkey. Higher resolution land use maps (STATIP with resolution $<2.5 \mathrm{~m}$ ) have been developed in recent years, but they do not go back to '90s.

RCs was calculated as follows (eqn. 1):

$$
R C=\frac{\text { Annual water yield }(\mathrm{mm})}{\text { Annual precipitation }(\mathrm{mm})}
$$

RCs was obtained for the 48 watersheds considered and then estimated for various types of land uses. We could apply this simple procedure as the study area was homogenous regarding soil, topography (Tab. 2), climate, and human influence (land use practices and habits), and very flat compared with other basins across the country.

Precipitation data used in the RC calculation were spatially interpolated using the IDW tool of ARcGIS $^{\circledR}$ and calculated for 
Tab. 2 - List of the variables used in the PCA and correlations between variables and the first three eigenvalues (F1 to F3).

\begin{tabular}{lrrrrrrrr}
\hline Variable & Obs & Min & Max & Mean & STD & F1 & F2 & F3 \\
\hline Deciduous forest area $\left(\mathrm{km}^{2}\right)$ & 48 & 0.32 & 222.61 & 45.22 & 53.13 & 0.822 & 0.202 & 0.150 \\
Coniferous forest area $\left(\mathrm{km}^{2}\right)$ & 48 & 0.00 & 100.19 & 7.56 & 18.89 & 0.782 & 0.213 & -0.091 \\
Mixed forest area $\left(\mathrm{km}^{2}\right)$ & 48 & 0.00 & 183.83 & 18.78 & 36.04 & 0.846 & 0.315 & -0.128 \\
Forest area $\left(\mathrm{km}^{2}\right)$ & 48 & 1.15 & 464.02 & 71.56 & 95.62 & 0.930 & 0.273 & 0.017 \\
Forest intensity $\left(\mathrm{km}^{2} / \mathrm{km}^{2}\right)$ & 48 & 2.09 & 99.93 & 53.32 & 22.77 & -0.054 & 0.863 & 0.162 \\
Settlement area $\left(\mathrm{km}^{2}\right)$ & 48 & 0.00 & 17.76 & 1.73 & 3.68 & 0.720 & -0.192 & 0.337 \\
Settlement intensity $\left(\mathrm{km}^{2} / \mathrm{km}^{2}\right)$ & 48 & 0.00 & 8.99 & 1.08 & 1.86 & 0.158 & -0.407 & 0.485 \\
Perennial farmland area $\left(\mathrm{km}^{2}\right)$ & 48 & 0.00 & 25.94 & 1.17 & 4.53 & 0.045 & 0.009 & -0.298 \\
Annual farmland area $\left(\mathrm{km}^{2}\right)$ & 48 & 0.00 & 321.54 & 42.55 & 61.48 & 0.837 & -0.321 & 0.002 \\
Total farmland area $\left(\mathrm{km}^{2}\right)$ & 48 & 0.00 & 322.72 & 43.72 & 61.74 & 0.837 & -0.319 & -0.020 \\
Farmland intensity $\left(\mathrm{km}^{2} / \mathrm{km}^{2}\right)$ & 48 & 0.00 & 89.71 & 31.41 & 23.26 & 0.019 & -0.785 & 0.019 \\
Rangeland area $\left(\mathrm{km}^{2}\right)$ & 48 & 0.00 & 194.80 & 18.28 & 31.76 & 0.877 & -0.016 & -0.229 \\
Rangeland intensity $\left(\mathrm{km}^{2} / \mathrm{km}^{2}\right)$ & 48 & 0.00 & 40.43 & 12.86 & 9.91 & 0.046 & -0.074 & -0.650 \\
Watershed size $\left(\mathrm{km}^{2}\right)$ & 48 & 17.27 & 968.92 & 137.06 & 174.40 & 0.995 & 0.030 & -0.024 \\
Mean discharge $\left(\mathrm{m}^{3} / \mathrm{sec}^{2}\right)$ & 48 & 0.19 & 7.71 & 1.53 & 1.80 & 0.894 & 0.235 & 0.196 \\
Water yield $(\mathrm{mm})$ & 48 & 139.69 & 1039.62 & 387.89 & 206.31 & -0.162 & 0.587 & 0.644 \\
Annual precipitation $(\mathrm{mm})$ & 48 & 446.41 & 761.98 & 627.69 & 79.21 & -0.015 & -0.206 & 0.666 \\
RC $(\mathrm{mm} / \mathrm{mm})$ & 48 & 0.24 & 1.79 & 0.62 & 0.32 & -0.159 & 0.664 & 0.523 \\
Mean elevation $(\mathrm{m})$ & 48 & 74.91 & 841.72 & 347.77 & 204.56 & -0.003 & 0.773 & -0.354 \\
Mean slope $(\%)$ & 48 & 10.46 & 45.60 & 24.63 & 9.29 & -0.098 & 0.780 & -0.324 \\
\hline
\end{tabular}

each watershed. Annual water yield was calculated using daily streamflow data. For each of the 48 watersheds, $\mathrm{RC}$ was obtained by dividing the annual water yield by the annual precipitation of the period for which streamflow data were available. To this purpose, we assume that watershed size significantly affects water yield, but not the RC We tested this assumption by plotting watershed size against RC.

\section{Data analysis}

PCA is an ordination method widely used to extract a set of values of linearly uncorrelated components from a set of possibly correlated variables (Chang et al. 2009, Jolliffe 2002). As the variable units were different,

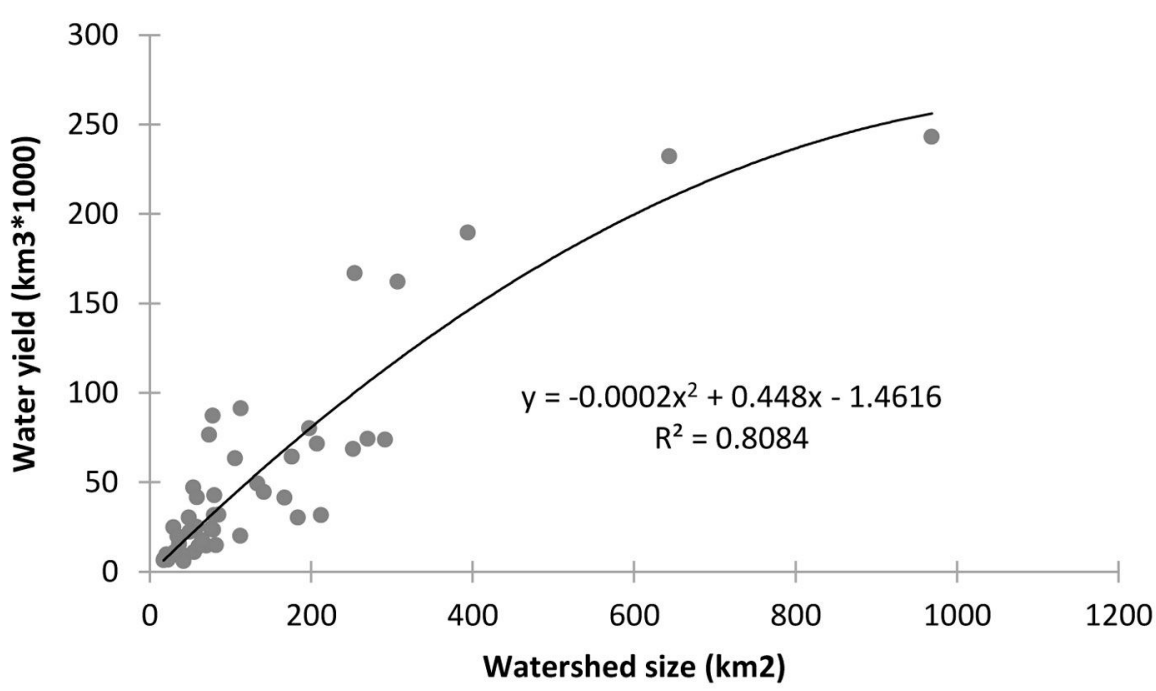

Fig. 2 - Relationship between water yield and watershed size. The annual water yields of the sub-watersheds plotted against watershed size. the z-transformation before analysis.

The Mann-Kendall trend test (Mann 1945, Kendall 1975) was used to detect possible trends in the RCs over the period 19902012 .

\section{Estimation of Runoff Coefficients (RCs)}

Measured RCs were then used to estimate average RCs for four basic land use types (forests, farmlands, rangelands, and settlements) by applying the equation reported below on data from 28 sub-watersheds (eqn. 2):

$$
\begin{aligned}
R C_{w} & =R C_{\text {forest }} \cdot \frac{A_{\text {forest }}}{A_{\text {watershed }}}+ \\
& +R C_{\text {farm }} \cdot \frac{A_{\text {farm }}}{A_{\text {watershed }}}+ \\
& +R C_{\text {range }} \cdot \frac{A_{\text {range }}}{A_{\text {watershed }}}+ \\
& +R C_{\text {settle }} \cdot \frac{A_{\text {settle }}}{A_{\text {watershed }}}
\end{aligned}
$$

where $R C_{\mathrm{w}}$ is the runoff coefficient of the sub-watershed; $R C_{\text {forest }}, R C_{\text {farm }}, R C_{\text {range }}, R C_{\text {settle }}$ are the runoff coefficient of the relevant land use; $A_{\text {watershed }}$ is the area of the sub-watershed $\left(\mathrm{km}^{2}\right) ; A_{\text {forest }}, A_{\text {farm }}, A_{\text {range, }}, A_{\text {settle }}$ are the areas of the relevant land use $\left(\mathrm{km}^{2}\right)$.

$\mathrm{RC}$ values for each land use were derived by an optimized approach based on the calculation and comparison of the sum of least square errors. In this way, RCs for the watersheds were converted to RCs for land uses (forest, rangelands, farmlands, and settlements). Then, RCs for the 28 watersheds were recalculated using the $\mathrm{RC}$ values of the land uses. Finally, estimated and observed water yields were plotted on a graph to verify their linear relationship and its reliability. Water yields were calculated by the multiplication of a hypothetical $1 \mathrm{~mm}$ rainfall with the estimated RCs and the watershed size. The same procedure described above was applied on the remaining 20 watersheds to verify the reliability of the approach.

\section{Results and discussion}

As expected, water yield of watersheds increased with their size (Fig. 2), though RC was not affected by watershed size (Fig. 3). Such evidence supports our preliminary assumption on the homogeneity of watershed attributes in the region considered, by rejecting watershed size as a factor determining RC. Instead, principal component analysis revealed that the main factor affecting $\mathrm{RC}$ was land use proportion (land use area/watershed area) of forests, farmlands, rangelands and settlements.

The dominant land use in the 48 sub-watersheds analyzed was forestland, followed by farmlands, rangelands, and settlements (Fig. 4). In the studied region, the total area covered by forests increased by about $5 \%$ from 1990 to 2012 , farmlands decreased by $0.3 \%$, 
while the most significant decrease $(26.3 \%)$ occurred for rangelands. Settlements increased by $26.0 \%$ over the same period, though their overall cover did not exceed $1.5 \%$ of the total watershed area.

Most significant changes in land use likely to affect $\mathrm{RC}$ were due to an increase in forest cover and a decrease in rangelands. Both the above changes can decrease water yield in watersheds. Forest cover is known to cause more evapotranspiration as compared with vegetation in rangelands (Legesse et al. 2003). This is also the case for extreme flow events. Despite some authors have suggested that forest cover may increase RC in the case of large flood events (Nan et al. 2011), many studies put forward the positive or neutral role of forests in flood prevention (Serengil et al. 2011).

The role of watershed imperviousness due to sprawl has been largely studied and is known to be a major cause of increased flooding (Suriya \& Mudgal 2012, Miller et al. 2014). However, in our study the percentages of settlements was very low compared to other land uses, despite the fact the region analyzed is the most populated of the whole country.

$\mathrm{RC}$ values obtained from the relationship between land use and runoff were 0.40 for forests, 0.49 for farmlands, 0.61 for rangelands, and 0.95 for settlements. $\mathrm{R}^{2}$ values for model construction and verification were $0.80(p<0.01)$ and $0.70(p<0.01)$, respectively (Fig. 5). This means that the predicted $\mathrm{RC}$ values were close to actual RC values. Therefore, RCs estimated for each land use were combined in a single series by taking their average value (Fig. 6), and used to assess RCs for the whole period 1990-2012.

The variation through time of the average $\mathrm{RC}$ values obtained as described above were examined using the Mann-Kendall test, but no significant trends were detected (trend $=$ -2.24 , mean $=17.5, p>0.05)$. Significant and

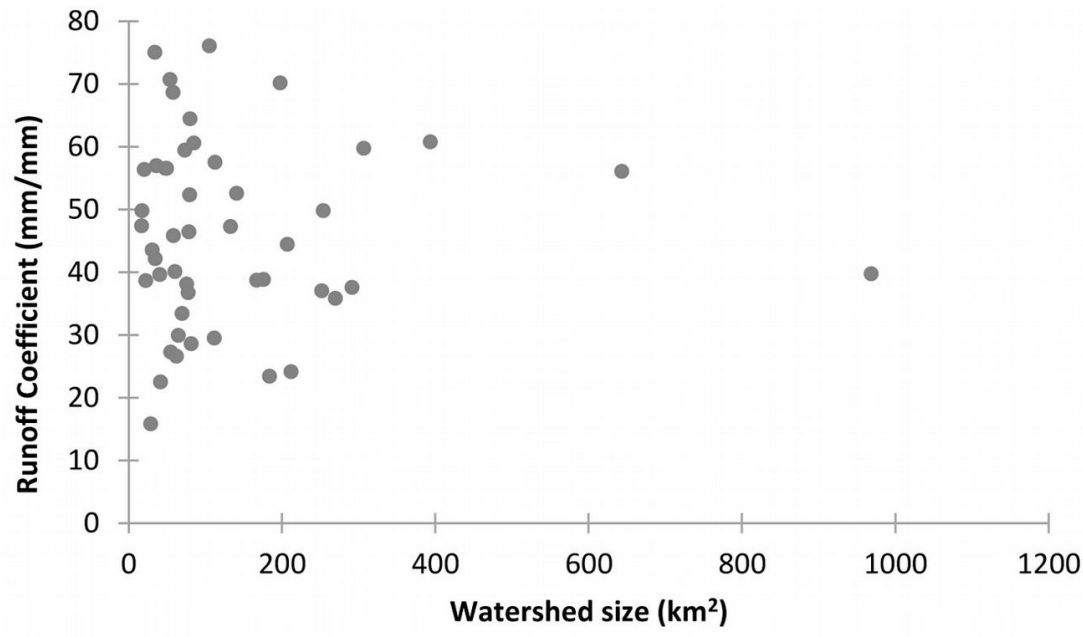

Fig. 3 - Relationship between annual runoff coefficient and watershed size. The average RCs of the sub-watersheds plotted against watershed size.

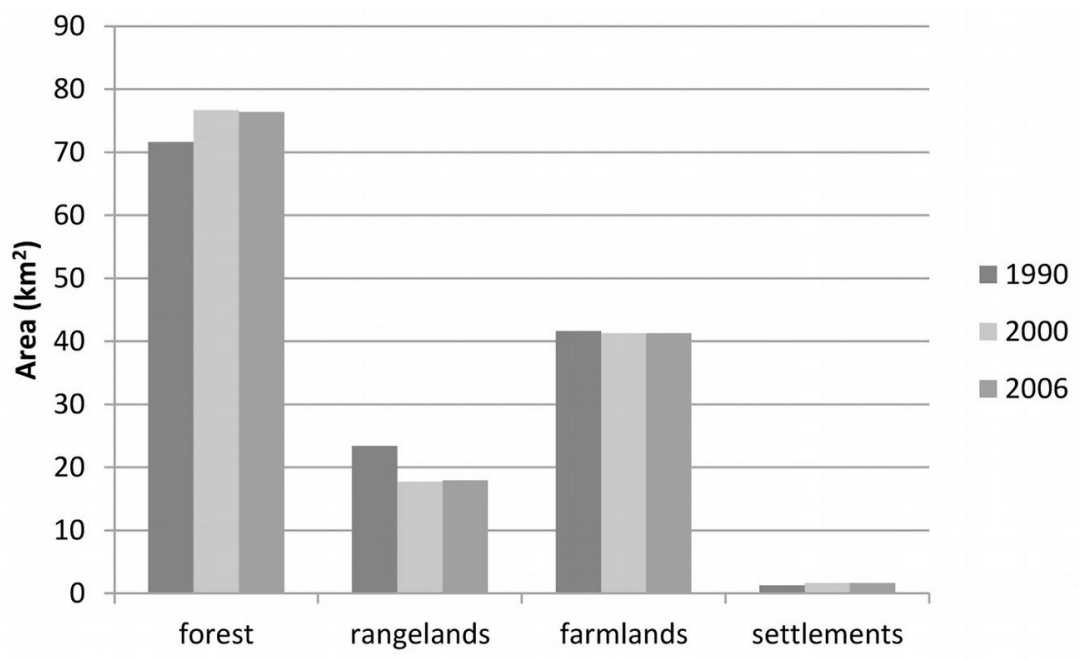

Fig. 4 - Average land uses in the studied watersheds and change in land use types from 1990 to 2006 . Standard deviations were $2.83 \mathrm{~km}^{2}$ for forests, $3.21 \mathrm{~km}^{2}$ for rangelands, $0.20 \mathrm{~km}^{2}$ for farmlands and $0.21 \mathrm{~km}^{2}$ for settlements.
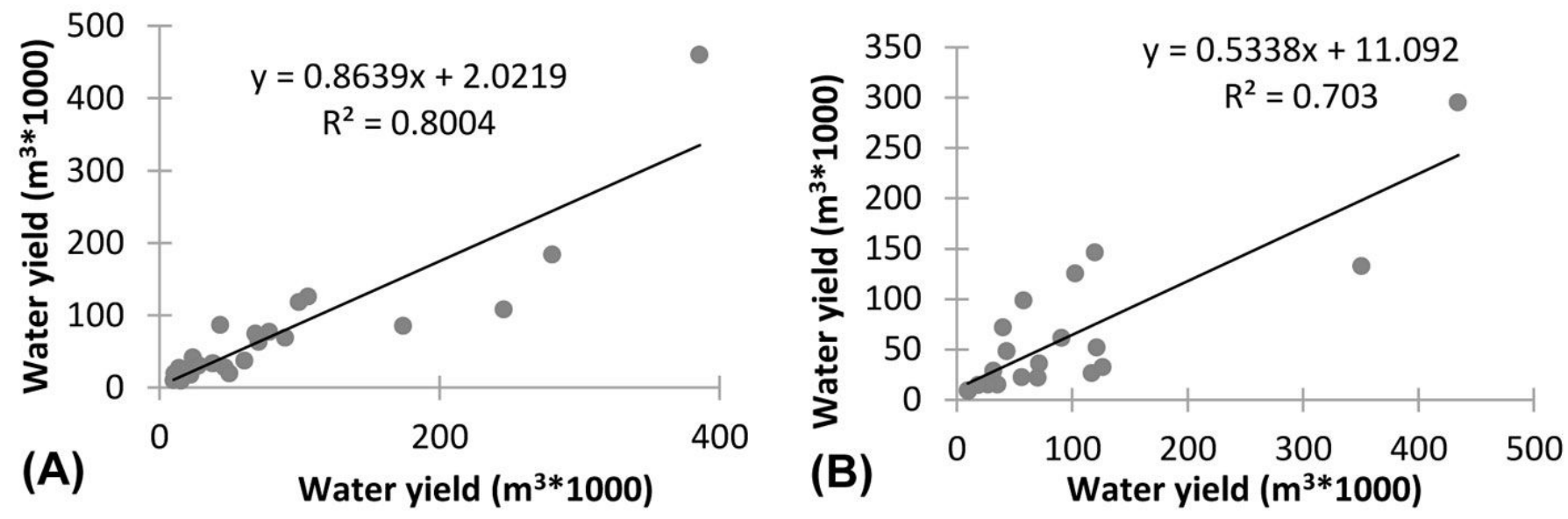

Fig. 5 - RC prediction and validation procedure. The observed RCs of the 28 sub-watersheds were plotted against predicted RCs (A) and the same procedure was done for the remaining 20 sub-watersheds for validation (B). 

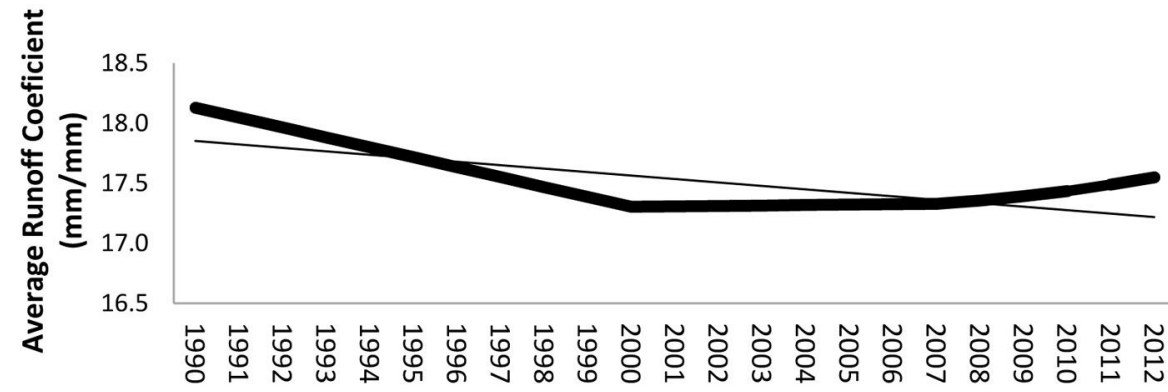

Fig. 6 - Temporal change in estimated mean RC of the sub-watersheds.

Tab. 3 - Mann-Kendall test results for precipitation.

\begin{tabular}{lccccc}
\hline Station & $\begin{array}{c}\text { Observation } \\
\text { dates }\end{array}$ & $\begin{array}{c}\text { Mean annual } \\
\text { precipitation } \\
\text { (mm/year) }\end{array}$ & $\begin{array}{c}\text { Trend } \\
\mathbf{( \% )}\end{array}$ & $\begin{array}{c}\text { Test } \\
\text { results }\end{array}$ & Prob \\
\hline Edremit & $1932-2012$ & 686.2 & -2.54 & Decreasing & 0.03 \\
Kocaeli & $1930-2012$ & 663.9 & 0.5 & No increase/decrease & 0.12 \\
Çanakkale & $1930-2012$ & 547.8 & -0.12 & No increase/decrease & 0.36 \\
Kumköy & $1951-2012$ & 667.9 & 2.54 & Increasing & 0.03 \\
(Istanbul) & & & & & \\
Kirklareli & $1930-2012$ & 479.6 & -1.88 & No increase/decrease & 0.08 \\
Tekirdağ & $1931-2012$ & 499.4 & 0.15 & No increase/decrease & 0.53 \\
Yalova & $1956-2012$ & 621.5 & -0.07 & No increase/decrease & 0.67 \\
Bursa & $1931-2012$ & 601.2 & -1.82 & No increase/decrease & 0.08 \\
\hline
\end{tabular}

Tab. 4 - Mann-Kendall test results for temperature.

\begin{tabular}{lccccc}
\hline Station & $\begin{array}{c}\text { Observation } \\
\text { dates }\end{array}$ & $\begin{array}{c}\text { Mean annual } \\
\text { temperature } \\
\left({ }^{\circ} \mathbf{C}\right)\end{array}$ & $\begin{array}{c}\text { Trend } \\
(\mathbf{( \% )}\end{array}$ & Test results & Prob \\
\hline Edremit & $1959-2012$ & 16.4 & 0.46 & No increase/decrease & 0.19 \\
Kocaeli & $1933-2012$ & 14.6 & 0.92 & No increase/decrease & 0.23 \\
Çanakkale & $1930-2012$ & 14.8 & 1.92 & No increase/decrease & 0.07 \\
Kumköy & $1951-2012$ & 13.8 & 0.11 & No increase/decrease & 0.53 \\
(Istanbul) & & & & & \\
Kirklareli & $1963-2012$ & 13.1 & 1.07 & No increase/decrease & 0.18 \\
Tekirdağ & $1940-2012$ & 13.8 & 0.85 & No increase/decrease & 0.26 \\
Yalova & $1958-2012$ & 14.5 & 2.38 & Increasing & 0.04 \\
Bursa & $1930-2012$ & 14.1 & 0.61 & No increase/decrease & 0.19 \\
\hline
\end{tabular}

contrasting trends in precipitation were detected for only two stations (Tab. 3). Increasing precipitation through time was observed for Kumkoy, located in the north part of the region near the Black sea coast, while a decreasing precipitation trend was found for Edremit, near the Aegean sea coast. Although located in the same region, these two stations are under the influence of different air masses and conditions. The Kumkoy station is on a flat terrain but reflects a typical Black sea climate, which receives the precipitation from north to south direction in winter months. By contrast, the Aegean Sea coast is characterized by a typical Mediterranean climate with high temperatures, high evapotranspiration and soil water deficit in the summer time.

All stations showed increasing trends of mean annual temperature although only
Yalova showed a significant increasing trend (Tab. 4). However, a general increase in temperature was not statistically supported at the regional scale. We can argue that the observed significant changes in annual precipitation for the period 1990-2012 may be considered as due to local variations, and not to a general trend at the regional scale. Overall, based on our results, climate change cannot be considered as a factor potentially affecting water resources in the region analyzed.

\section{Conclusions}

Land use change in the fastest urbanizing region of Turkey did not cause a significant change in RC over the period 1990-2012. The conversions among various land uses in the last 30 years did not cause significant effects on RC. The share of settlements was quite low even though it is the most urbani- zed region of the country. The increase in forest cover and the decrease in rangelands over the study area can be seen as the main reason underlying the observed decrease in $\mathrm{RC}$. Indeed, forest cover is known as causing more evapotranspiration compared to rangelands, but producing at the same time higher quality water.

The hydrologic behaviors of different types of land use are well known, but local practices (afforestation, grazing and cropping techniques, settlement intensity etc) and climatic parameters have a large potential to influence hydrologic parameters. Therefore, local conditions should be taken into account when interpreting the results of changes in land use.

Based on our results, land use changes (especially for forests and rangelands) occurred in the period 1990-2012 did not seem to significantly affect RCs. Hence, we conclude that both land use and climate changes have not played a significant role in affecting the availability of water resources in this region during the past decades.

\section{Acknowledgements}

This study was supported by TUBITAK (The Scientific and Technological Research Council of Turkey) Project number: 112Y 096.

\section{References}

Atmis E, Özden S, Lise W (2007). Urbanization pressures on the natural forests in Turkey: an overview. Urban Forestry and Urban Greening 6 (2): 83-92. - doi: 10.1016/j.ufug.2007.01.002

Chang FJ, Wu TC, Tsai WP, Herricks EE (2009). Defining the ecological hydrology of Taiwan rivers using multivariate statistical methods. Journal of Hydrology 376: 235-242. - doi: 10.10 16/j.jhydrol.2009.07.034

Delgado JA, Nearing MA, Rice CW (2013). Conservation practices for climate change adaptation. Advances in Agronomy 121: 47-115. - doi: 10.1016/B978-0-12-407685-3.00002-5

Dibike Y, Prowse T, Shrestha R, Ahmed R (2012). Observed trends and future projections of precipitation and air temperature in the Lake Winnipeg watershed. Journal of Great Lakes Research 38: 72-82. - doi: 10.1016/j.jglr.2011.04. 005

Du J, Qian L, Rui H, Zuo T, Zheng D, Xu YC, Xu $Y$ (2012). Assessing the effects of urbanization on annual runoff and flood events using an integrated hydrological modeling system for Qinhuai River basin, China. Journal of Hydrology 464: 127-139. - doi: 10.1016/j.jhydrol.2012.06.057

Hromadtka HR, Yen CC (1989). The rational method in stormwater management modelling of peak flow flood control systems. II. Computer program application. Environmental Software 4 (3): 130-135. - doi: 10.1016/0266-9838(89)9004 3-9

ISKI (2013). Home page. Web site. [online] URL: http://www.iski.gov.tr/web/ 
Jolliffe IT (2002). Principal component analysis $\left(2^{\text {nd }}\right.$ edn). Springer Series in Statistics, New York, USA, pp. 488.

Karnosky DF (2003). Impacts of elevated atmospheric $\mathrm{CO}_{2}$ on forest trees and forest ecosystems: knowledge gaps. Environment International 29 (2-3): 161-169. - doi: 10.1016/S01604120(02)00159-9

Kendall MG (1975). Rank correlation methods Charles Griffin and Co., London, UK, pp. 202.

Kyselý J, Beguería S, Beranová R, Gaál L, LópezMoreno JI (2012). Different patterns of climate change scenarios for short-term and multi-day precipitation extremes in the Mediterranean Global and Planetary Change 98-99: 63-72. doi: 10.1016/j.gloplacha.2012.06.010

Legesse D, Vallet-Coulomb C, Gasse F (2003). Hydrological response of a catchment to climate and land use changes in Tropical Africa: case study South Central Ethiopia. Journal of Hydrology 275 (1-2): 67-85. - doi: 10.1016/S00221694(03)00019-2

León-Muñoz J, Echeverría $C$, Marcé R, Riss $\mathrm{W}$, Sherman B, Iriarte JL (2013). The combined impact of land use change and aquaculture on sediment and water quality in oligotrophic Lake Rupanco (North Patagonia, Chile, $40.8^{\circ} \mathrm{S}$ ). Journal of Environmental Management 128: 283-291. doi: 10.1016/j.jenvman.2013.05.008

Mann HB (1945). Nonparametric tests against trend. Econometrica 13: 245-259. - doi: 10.2307/ 1907187

Miller JD, Kim H, Kjeldsen TR, Packman J, Grebby S, Dearden R (2014). Assessing the impact of urbanization on storm runoff in a peri-urban catchment using historical change in impervious cover. Journal of Hydrology 515: 59-70. - doi: 10.1016/j.jhydrol.2014.04.011

Morrison J, Quick MC, Foreman MGG (2002). Climate change in the Fraser River watershed: flow and temperature projections. Journal of Hydrology 263: 230-244. - doi: 10.1016/S00221694(02)00065-3

Nan Y, Bao-hui M, Chun-kun L (2011). Impact analysis of climate change on water resources. Procedia Engineering 24: 643-648. - doi: 10.101 6/j.proeng.2011.11.2710

NC Turkey (2013). Turkey's fifth National communication under the UNFCCC. The Ministry of Environment and Urbanisation, Ankara, Turkey, pp. 290.
NIR Turkey (2013). National inventory report on land use, land use change and forestry. General Directorate of Forestry, Ankara, Turkey, pp. 42. [in Turkish]

Özhan S (2004). Watershed management. Publication no. 481, IU Faculty of Forestry Publications, Istanbul, pp. 384. [in Turkish]

Quirmbach M, Einfalt T, Langstädtler G (2012).

Climate change analysis of precipitation data for North Rhine-Westphalia. Atmospheric Research 109: 1-13. - doi: 10.1016/j.atmosres.2011.10.014 Ribalaygua J, Pino MR, Pórtole J, Roldán E, Gaitán E, Chinarro D, Torres L (2013). Climate change scenarios for temperature and precipitation in Aragón (Spain). Science of the Total Environment 463: 1015-1030. - doi: 10.1016/j.scitotenv.2013.06.089

Romanowicz RJ, Osuch M (2011). Assessment of land use and water management induced changes in flow regime of the Upper Narew. Physics and Chemistry of the Earth Parts A/B/C 36 (13): 662-672. - doi: 10.1016/j.pce.2011.04.012

Schoonover JE, Lockaby BG, Pan S (2005). Changes in chemical and physical properties of stream water across an urban-rural gradient in western Georgia. Urban Ecosystems 8: 107-124. - doi: 10.1007/s11252-005-1422-5

Schueler TR (2004). An integrated framework to restore small urban watersheds. Small Watershed Restoration Manual Series, Manual 1, Center for Watershed Protection, Ellicott City, MD, USA.

Senatore A, Mendicino G, Smiatek G, Kunstmann H (2012). Regional climate change projections and hydrological impact analysis for a Mediterranean basin in Southern Italy. Journal of Hydrology 399: 70-92. - doi: 10.1016/j.jhydrol.201 0.12 .035

Serengil Y, Gökbulak F, Özhan S, Hizal A, Sengönül K (2007). Alteration of stream nutrient discharge with increased sedimentation due to thinning of a deciduous forest in Istanbul. Forest Ecology and Management 246: 264-272. - doi: 10.1016/j.foreco.2007.04.008

Serengil Y, Swank WT, Riedel MS, Vose JM (2011). Conversion to pine: changes in timing and magnitude of high and low flows. Scandinavian Journal of Forest Research 26: 568-575. doi: 10.1080/02827581.2011.608710

Serengil Y, Inan M, Yurtseven I, Kiliç Ü, Uygur B (2012). Stream corridors as indicators of watershed land use: a case study in Istanbul. Bosque
33 (3): 345-352. - doi: 10.4067/S0717-9200201 2000300020

Shiliang S, Ma X, Xiao R (2014). Agricultural landscape pattern changes in response to urbanization at ecoregional scale. Ecological Indicators 40: 10-18. - doi: 10.1016/j.ecolind.2013.12.013 Sigaroodi SK, Ebrahimi S (2010). Effects of land use change on surface water regime (case study Orumieh lake of Iran). Procedia Environmental Sciences 2: 256-261. - doi: 10.1016/j.proenv.20 10.10.031

Sriwongsitanon N, Taesombat W (2011). Effects of land cover on runoff coefficient. Journal of Hydrology 410: 226-238. - doi: 10.1016/j.jhydrol.2011.09.021

Suriya S, Mudgal BV (2012). Impact of urbanization on flooding: the Thirusoolam sub watershed - a case study. Journal of Hydrology 412: 210219. - doi: 10.1016/j.jhydrol.2011.05.008

Tripathi S, Srinivas VV, Nanjundiah RS (2006). Downscaling of precipitation for climate change scenarios: a support vector machine approach. Journal of Hydrology 330: 621-640. - doi: 10.10 16/j.jhydrol.2006.04.030

Tu J (2009). Combined impact of climate and land use changes on streamflow and water quality in eastern Massachusetts, USA. Journal of Hydrology 379: 268-283. - doi: 10.1016/j.jhydrol.2 009.10.009

Yang T, Hao X, Shao Q, Xu C, Zhao C, Chen X, Wang W (2012). Multi-model ensemble projections in temperature and precipitation extremes of the Tibetan Plateau in the $21^{\text {st }}$ century. Global and Planetary Change 80: 1-13. - doi: 10.1016/j. gloplacha.2011.08.006

Wang S, Zhang Z, McVicar TR, Guo J, Tang Y, Yao A (2013). Isolating the impacts of climate change and land use change on decadal streamflow variation: assessing three complementary approaches. Journal of Hydrology 507: 63-74. doi: 10.1016/j.jhydrol.2013.10.018

Weatherhead EK, Howden NJK (2009). The relationship between land use and surface water resources in the UK. Land Use Policy 26S: S243S250. - doi: 10.1016/j.landusepol.2009.08.007

Zapata VM, Robledano F (2014). Assessing biodiversity and conservation value of forest patches secondarily fragmented by urbanisation in semiarid southeastern Spain. Journal for Nature Conservation 22 (2): 166-175. - doi: 10.1016/j.jnc. 2013.11.002 